ISSN 0206-5657. Вісник Львівського університету. Серія біологічна. 2020 Випуск 82. С. 110-120 Visnyk of the Lviv University. Series Biology. 2020. Issue 82. P. 110-120

УДК 582.323:581.9](477.83) https://doi.org/10.30970/vlubs.2020.82.09

\title{
SPHAGNUM MOSSES OF THE MALE POLISSYA (LVIV REGION)
}

\section{Z. Mamchur, Yu. Drach, S. Prytula}

Ivan Franko National University of Lviv

4, Hrushevskyi St., Lviv 79005, Ukraine

e-mail:dzvinkamamchur@gmail.com

The article summarizes current data about the condition and spread of Sphagnum mosses on the territory of Male Polissya in Lviv Region based on the material from our own field research, materials of National Herbarium of Ukraine $(K W)$, the Herbarium National Museum of Natural History of the National Academy of Sciences of Ukraine (LWS) and literature data. An annotated list of the species of the genus Sphagnum was compiled and it includes 15 species together with an indication of place and date of collection, the names of collectors, the spread in Ukraine and biotopes in which the species may occur according to The National Habitat Catalogue of Ukraine and EUNIS. Sphagnum fallax (Klinggr.) Klinggr., S. fimbriatum Wils. and $S$. palustre L. were determined as the most widespread species of the genus Sphagnum in the research area. Two species $S$. angustifolium and S. inundatum are indicated for the first time for the territory of Lviv region.

Six regionally rare species were found: S. capillifolium, S. cuspidatum, S. fallax, S. fimbriatum, S. obtusum and S. papillosum. The possible disappearance of a species Sphagnum centrale, $S$. contortum, $S$. flexuosum and $S$. obtusum on the territory of the Volytsky Botanical Reserve of national importance was established owing to the draining of wetlands.

Ecological groups of sphagnum species on the research area were analyzed, where the predominance of subheliophytes ( 7 species, $46.7 \%$ ), hygrophytes ( 13 species, $86.7 \%$ ), cold tolerant species ( 13 or $87.7 \%$ ) and acidophiles ( 8 species, $53.3 \%$ ) was identified.

The topicality of the study is determined by the fact that sphagnum mosses are spread much less frequently than other species from the division of bryophytes because they are confined to a narrow range of biotopes. With the drastic changes in the hydrological regime of the environment, which occurred during the second half of the twentieth century, due to the large areas of drained land, the processes of biotope dehydration became irreversible and some species of sphagnum could have disappeared from the territory of Male Polissya.

Due to the sensitivity of bryophytes, in particular species of the sphagnum genus, and due to a disturbance of the hydrological regime of wetlands, the waterlogged mixed coniferous forest in the vicinity of the village Kulychkiv is a promising territory for the creation of a new environmentally protected site or the extension of the Volytsky Botanical Reserve of national importance for the purpose of wetlands preservation here.

Keywords: sphagnum mosses, Male Polissya, Volytsky Botanical Reserve, biotopes

\section{Introduction}

The natural area of Male Polissya lies within four regions of Ukraine and covers the northern part of Lviv Region, the southern and southwestern parts of Rivne Region, and partly the north of Ternopil and Khmelnytsky Regions. In Lviv Region, Male Polissya is located within the Volyn-Podolian Upland and has the largest area of wetlands that constitute $59.7 \%$ of the swamps of Lviv Region plains [15]. During the second half of the twentieth century, large areas of these lands were damaged as a consequence of reclamation works, which had an adverse impact on the biogeocenotic cover. As a result, many species from the wetland habitats of this area are now on the verge of extinction and are listed in the Red Data Book of Ukraine (2009). Apparently, there

(C) Мамчур 3., Драч Ю., Притула С., 2020 
are reasons to assert that there has been a reduction in the biodiversity of mosses in this area, including sphagnum mosses.

Sphagnum mosses are an important component of the vegetation of sphagnum bogs in swampy forests and wet meadows. With a low need for mineral nutrition, sphagnum mosses can grow on poor soils. Due to their ecological, morphological and anatomical features, as well as the specifics of nutrition, sphagnum mosses are much less common than other species of the division of bryophytes. Instead, they are characterized by a fairly high moisture-holding capacity, as the tissues of these plants consist of two types of cells: dead hyaline cells and living chlorophyllose cells. Anatomical and morphological features of sphagnum mosses, particularly such adaptations as branching architecture, the size and location of leaves on branches and the presence of hyaline cells, enable them to store and transport water. In all species, dead hyaline cells of leaves and stems provide water storage. After surviving significant dehydration, dead hyaline cells are capable of filling with water at the lowest moisture supply, which enables plants to maintain their life functions $[7,20,22]$. This feature is reflected in the name of the genus: in Greek "sphagnus" means "a sponge".

With the dramatic changes in the hydrological regime of the environment that occurred during the second half of the twentieth century, considering the fact that the area of drained land in this locality was the largest in Ukraine (513.2 thousand hectares, which constitutes $23.5 \%$ of the region's area) [18], dehydration processes in the biotopes could have become irreversible and sphagnums could have disappeared from certain areas.

Today, there is little information about sphagnum mosses of Male Polissya. From the present-day botanical reserve of national importance "Volytsky", we have data provided by the Ukrainian researcher, geobotanist and swamp scientist E. Bradis (1950s) [23] and Lviv botanist O. Kuzyarin [14]. In recent decades, studies of coal dumps in the Lviv-Volyn mining region and within the floodplain of the Western Bug River basin have added to the list of species of the genus Sphagnum $[13,14]$.

To understand the present state of the biodiversity and the processes that occur in the research area, it is necessary to conduct an inventory of species diversity of the biota in the first place. Therefore, the aim of our research was to summarize information on the species composition and current distribution of sphagnum mosses on the territory of Male Polissya within Lviv Region.

\section{Research Area}

The western part of Male Polissya is located within the Galicia-Volyn basin. Upper Cretaceous marls with waterproof clay crust are the most common type of rock there. The basin location and, accordingly, the complicated runoff of precipitation contribute to waterlogging of the territory $[8,9]$.

The area is characterized by water-glacial, alluvial and aeolian (sandy and loess) formations and associated forest ridges, sand dunes and sandy "pine" floodplain terraces, sprawling leveled plains of water-glacial and fluvial accumulation along the main rivers - the Bug and the Styr - and their tributaries [15]. The physical and geographical region of Male Polissya forms an inner lowland with lower absolute heights than the surrounding uplands. The preserved vegetation is dominated by forests, of which the main type are forests consisting of Pinus sylvestris L. mixed with Quercus robur L., Populus sp., Betula sp., Alnus glutinosa (L.) Gaerth and occasionally Carpinus betulus L. The valley of the Western Bug River is dominated by meadows, whereas swamps remain in the valleys of small rivers: the Solokiya, the Bolotnya, the Rata, and the Mlynivka [8, 9]. 


\section{Materials and Methods}

In the study, we used materials collected during our own field research (35 specimens), data from the National Herbarium of Ukraine (KW), the Museum of Natural History Herbarium, National Academy of Sciences of Ukraine (LWS), and literature data [3, 13, 14, 23].

In the field research, conducted during the vegetation periods of 2018-2019 on the territory of Male Polissya within Lviv Region, the traditional route method was used. The largest number of specimens and the largest number of sphagnum moss species were collected in the Volytsky Botanical Reserve and the adjacent wetlands, in particular in the forests around the village of Kulychkiv (Fig. 1). Collection and determination were performed according to traditional methods. Latin taxon names were used in accordance with the nomenclature developed by M. Boiko [2]. Ecological groups of bryophytes in relation to light and moisture were determined on the basis of our own observations using the values of the Ellenberg indicators elaborated by R. Düll [5] and M.O. Hill et al. [10].

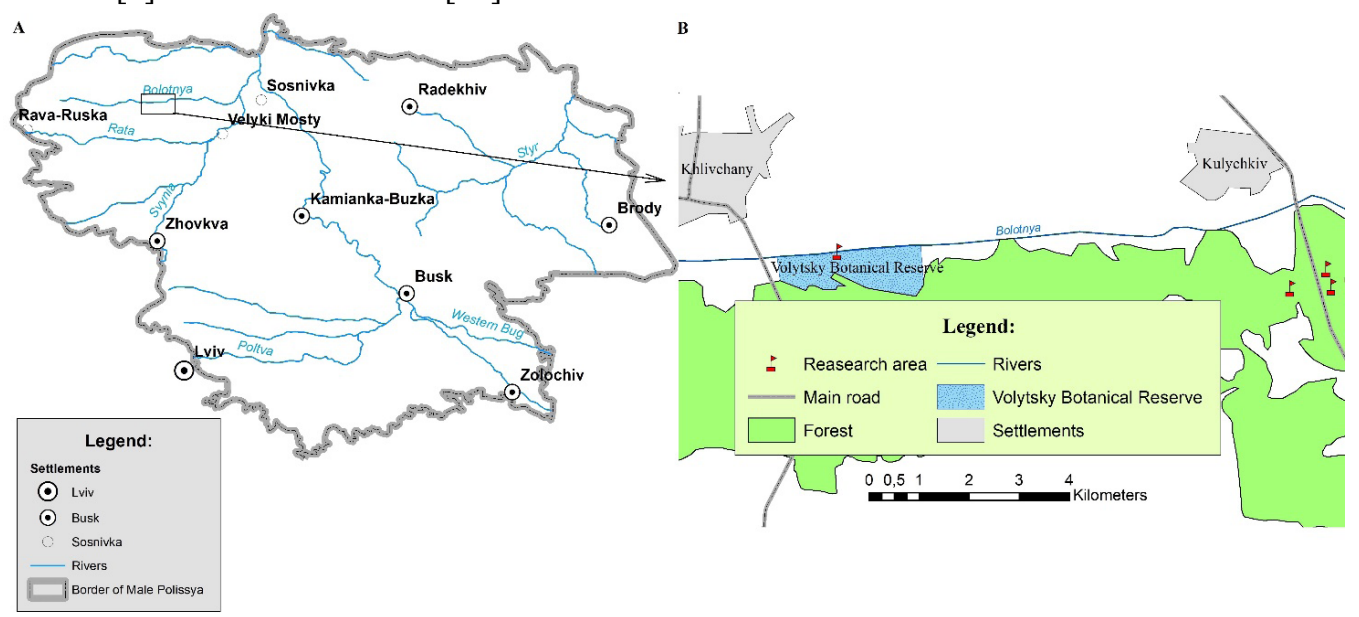

Fig. 1. Map of the research area: (A) Male Polissiya within Lviv Region; (B) the Volytsky Botanical Reserve of national importance and the waterlogged mixed coniferous forest in the vicinity of Kulychkiv village

\section{Results and Discussion}

Based on the results of our own field research as well as the herbarium and literature data, a list including 15 species of Sphagnum mosses of Male Polissiya was compiled. It indicates a considerable species diversity, as only 26 species of the genus Sphagnum are known for Volyn Polissiya, and 32 - for Ukraine [2].

The Volytsky Botanical Reserve of national importance located within Sokal District of Lviv Region with the area of 150 hectares was founded in 1978 with the aim to preserve the sedge-sphagnum functional group in the swampy valley of the Bolotnya River (now Khlivchanske Forestry of the Rava-Ruska Forestry State Enterprise - 22, 23, 24 forest quarters).

E. Bradis previously described this territory as a complex of marshes with Eriophorum vaginatum and species of the genus Carex and elevated areas covered with a continuous sphagnum carpet of Sphagnum palustre ${ }^{1}$ mixed with Sphagnum flexuosum [3]. Today, the mesotrophic swamp of the Volytsky Botanical Reserve has undergone significant changes due to the creation of drainage reclamation canals in the swampy valley of the Bolotnya River. As a consequence of

Species authors are indicated in the annotated list 
the violation of the hydrological regime, there has been a significant decrease in the groundwater level, which in different periods can decline from 0.80 to $1.4 \mathrm{~m}$ [21]. In addition, self-afforestation by Pinus sylvestris can now be observed in this area.

Other research sites - the swampy forests around the village of Kulychkiv ( 2 and 3 forest quarters) - include mixed coniferous forests where areas with undisturbed hydrological regime have been partially preserved. Five species of sphagnum mosses with a fairly significant projection cover (over $50 \%$ ) were found in this area.

Having surveyed the swamps of the Volytsky Botanical Reserve and the forests around the village of Kulychkiv, we identified seven species of the genus Sphagnum: S. angustifolium (1 locality), S. cuspidatum (2), S. fallax (3), S. fimbriatum (3), S. girgensohnii (1), S. palustre (5) i S. squarrosum (1) (Fig. 2, Table).

According to E. Bradis, such species as Sphagnum centrale, S. contortum, S. obtusum, and $S$. flexuosum were found in the vicinity of Khlivchany village. To date, we have not confirmed the distribution of these species; other researchers (O. Kuzyarin) did not find them either. It is possible that these species disappeared as a result of reclamation drainage works carried out in this territory and the associated disappearance or reduction of biotopes suitable for their life.

Considering the complexity of the identification of species of $S$. recurvum complex [6], the latter could have been included here by mistake. Most of the specimens that we found belong to $S$. fallax, and one specimen belongs to $S$. angustifolium.

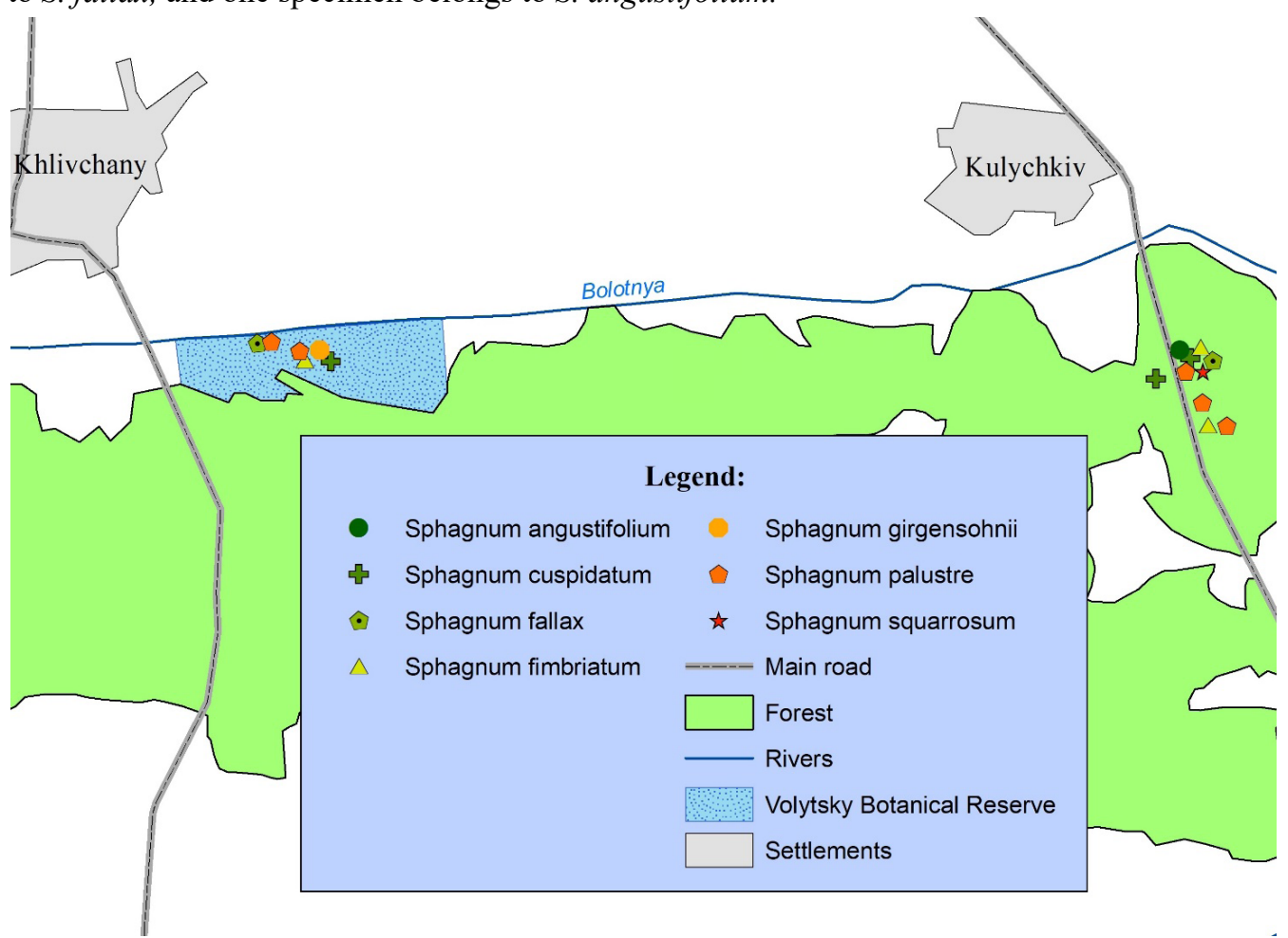

Fig. 2. Distribution of mosses genus Sphagnum on the territory of Volytsky Botanical Reserve of national importance and the waterlogged mixed coniferous forest in the vicinity of Kulychkiv village

According to our findings and materials of the Museum of Natural History Herbarium, National Academy of Sciences of Ukraine (LWS) as well as literature sources on Male Polissiya 

S. inundatum, S. magellanicum, S. palustre, S. papillosum, S. squarrosum occur in other parts of the research area. The most common species of the genus Sphagnum in the area under study are S. palustre, S. fimbriatum i $S$. fallax.

Environmental conditions, particularly the mode of humidification and lighting, are extremely important for sphagnum mosses (Table).

Ecological analysis of the studied species by their response to light indicates the predominance of species that prefer moderately and well-lit areas - subheliophytes (7 species, $46.7 \%$ ), heliophytes ( 5 species, $33.3 \%$ ), and hemiscyophytes ( 3 species, $20 \%$ ) on the territory of Male Polissya within Lviv Region. Anatomical and morphological features of sphagnum mosses account for the predominance of light-loving species.

In terms of temperature regime, cold-tolerant species predominate $(13$, or $87.7 \%)$ and two species are indifferent to temperature $(13.3 \%)$. Sphagnums include species that inhabit swamps and wetlands; therefore, they are dominated by hygrophytes (13 species $-86.7 \%$ ).

In terms of the reaction to the substrate, predominate acidophiles ( 8 species, $53.3 \%)$ and hyperacidophiles ( 4 species, $26.7 \%$ ) - the species that are adapted to the conditions of acidic and highly acidic substrate. We detected slightly fewer subacidophiles ( 3 species $-20 \%)$.

The characteristic life form of sphagnum facilitates the formation of a continuous carpet of many intertwined plant stems, due to which sphagnum mosses can reduce evaporation and retain water for a long time.

Species composition and ecological characteristics of sphagnum mosses of Male Polissya within Lviv Region

\begin{tabular}{|l|l|}
\hline \multicolumn{1}{|c|}{ Species } & \multicolumn{1}{c|}{ Ecological characteristics } \\
\hline Sphagnum angustifolium & subheliophyte, cold-tolerant, hygrophyte, acidophile \\
Sphagnum capillifolium & subheliophyte, cold-tolerant, hygrophyte, acidophile \\
Sphagnum centrale & subheliophyte, cold-tolerant, hygrophyte, hyperacidophile \\
Sphagnum contortum & heliophyte, cold-tolerant, hygrophyte, subacidophile \\
Sphagnum cuspidatum & heliophyte, cold-tolerant, hygrophyte, hyperacidophile \\
Sphagnum fallax & subheliophyte, cold-tolerant, hygrophyte, acidophile \\
Sphagnum fimbriatum & hemiscyophyte, cold-tolerant, hygrophyte, acidophile \\
Sphagnum flexuosum & subheliophyte, cold-tolerant, hygromesophyte, acidophile \\
Sphagnum girgensohnii & hemiscyophyte, cold-tolerant, hygrophyte, subacidophiles \\
Sphagnum inundatum & subheliophyte, indifferent to temperature, hygrophyte, acidophile \\
Sphagnum magellanicum & heliophyte, cold-tolerant, hygrophyte, hyperacidophile \\
Sphagnum obtusum & heliophyte, cold-tolerant, hygrophyte, acidophile \\
Sphagnum palustre & subheliophyte, cold-tolerant, hygromesophyte, acidophile \\
Sphagnum papillosum & heliophyte, cold-tolerant, hygrophyte, hyperacidophile \\
Sphagnum squarrosum & hemiscyophyte, indifferent to temperature, hygrophyte, subacidophile \\
\hline
\end{tabular}

Among the abovementioned species, six are rare for the region under study: Sphagnum capillifolium, S. cuspidatum, S. fallax, S. fimbriatum, S. obtusum and S. papillosum [1]. Sphagnum fimbriatum, which was found in the Volytsky Botanical Reserve and in the waterlogged mixed coniferous forest near the village of Kulychkiv, is included in the list of plant species under partial protection in Poland [19].

Due to the sensitivity of mosses, especially species of the genus Sphagnum, to disturbances of the hydrological regime of wetlands, the waterlogged mixed coniferous forest near the village of Kulychkiv can be a promising area for the creation of a new conservation facility. Alternatively, this area can be included into the Volytsky Botanical Reserve with the aim of protecting the sedge-sphagnum forest swamp here.

Sphagnum mosses are important components of many swamps and wetlands that form the living conditions for other components. Therefore, they are known as "ecosystem engineers". 
Due to such properties, sphagnum mosses can be used as sensitive bioindicators at the beginning of these processes [16].

Changes in the hydrological regime, the chemical composition, the acidity of the substrate, lighting and temperature regime can lead to the complete loss of these species from the natural environment. Such changes can be observed in the study area and are a consequence of both direct anthropogenic intervention (direct destruction of the biotopes by hydraulic engineering, the lowering of groundwater levels through drainage reclamation works, afforestation resulting from the irrationally chosen conservation regime, etc.) and a probable global climate change.

It is extremely important to preserve sphagnum mosses habitats, especially bogs and mesotrophic swamps, which have disappeared en masse in recent decades. It is also important to ensure the quality of the biotopes, as another factor that adversely affects the viability of sphagnum is the entry of nutrients from agricultural lands. Most peat mosses grow in nutrient-poor habitats, and eutrophication through anthropogenic activity exerts a negative influence on their life processes. Swiss bryologists suggest creating buffer zones large enough to protect wetland biotopes with sphagnum mosses from agricultural farms. It should be noted that in Switzerland all species of the genus Sphagnum are protected at the state or regional levels [11].

The species composition and distribution of sphagnum mosses in Male Polissya requires further detailed study, as the inventory of these species will provide an opportunity to thoroughly assess the consequences of land drainage in Lviv Region. Preservation of sphagnums and their habitats on the territory of Male Polissya is important inasmuch as swamps are peat sponges that retain moisture and maintain normal water levels of rivers not only of Male Polissya but also of the Volyn-Podolian Upland.

\section{Annotated list of the species of the genus Sphagnum for the natural area of Male Polissya (Lviv Region)}

The annotated list has been compiled based on the materials of our own study, data from Herbaria (KW, LWS), and literature sources [13, 14, 23].

The list for each species indicates:

- name and its synonyms in brackets:

- sites of collection:

- collectors' names and collection dates, or literature data:

- distribution in Ukraine [2, 23]:

- biotopes where the species occurs according to the National Habitat Catalogue of Ukraine (NHB) [17].

- biotopes according to EUNIS [4].

Sphagnum angustifolium (C.Jensen ex. Russow) C.Jensen - Sokal District: near Kulychkiv, 2 forest quarter, mixed swampy forest, $50^{\circ} 17^{\prime} 07.5^{\prime \prime} \mathrm{N} 24^{\circ} 06^{\prime} 20.8^{\prime \prime} \mathrm{E}$ (Drach, Mamchur, 2018).

Distribution in Ukraine: Carpathian Mountains, Polissya.

NHB: 54.1 Raised bogs. 54.2 Spring fens. Б3 Mesotrophic mires. 52.1.2 Rich fens with calcium-tolerant sphagnum mosses Д1.7.1 Eutrophic swamps with layer of black alder or birch.

EUNIS: D1.1 Raised bogs. D2.2 Valley mires, poor fens and transition mires D2.3: Transition mires and quaking bogs. D4.1 Rich fens, including eutrophic tallherb fens and calcareous flushes and soaks. G1.5 Broadleaved swamp woodland on acid peat. 
Sphagnum capillifolium (Ehrh.) Hedw. - Sokal District: Chervonohrad mining region, coal dumps of mines «Vizejs’ka» (Kuzyarin, 2013; LWS).

Distribution in Ukraine: Polissya, Carpathian Foothills, Carpathian Mountains, Forest steppe, Steppe.

NНВ: Б4.1 Raised bogs. Б4.2 Spring fens. Д1.5.3 Wet oligomesotrophic birch forests. Д2.2.3 Wet scots pine forests. Д2.2.5 Arolla pine forests. Д2.5.1 Bogs with spruce layer. Д2.5.2 Bogs witha layer of pine. C3.5 Anthropogenic outcrops, spoil tips and tailings without vegetation.

EUNIS: D1.1 Raised bogs. D2.3 Transition mires and quaking bogs. G3.E Nemoral bog conifer woodland. G4.1 Mixed swamp woodland. X04: Raised bog complexes. G5.6 Early-stage natural and semi-natural woodlands and regrowth. J6.5 Industrial waste.

Sphagnum centrale C. Jensen - Sokal District: near Khlivchany, eutrophic sedge-sphagnum swamp, (1956, Bradis, Kucheryava, Zerov; KW); near Prystan, swamp alder forest (Bradis, Kucheryava, 1956; KW).

Distribution in Ukraine: Carpathian Mountains, Polissya, Forest steppe, Steppe.

NHB: Б4.2. Spring fens. Д1.7.2 Bogs with layer of birch. Д2.1.1 Lowland spruce forests.

EUNIS: D2.3 Transition mires and quaking bogs. G1.5 Broadleaved swamp woodland on acid peat. G3.1 Abies and Picea woodland. G4.1 Mixed swamp woodland.

Sphagnum contortum Schultz - Sokal District: near Prystan, swamp alder forest (Bradis, Kucheryava, 1956; KW).

Distribution in Ukraine: Polissya, Carpathian Mountains, Forest steppe, Steppe.

NHB: 52.1.2 Rich fens with calcium-tolerant sphagnum mosses. 53 Mesotrophic mires. Б4.2. Spring fens.

EUNIS: D2.3 Transition mires and quaking bogs. D4.1 Rich fens, including eutrophic tallherb fens and calcareous flushes and soaks.

Sphagnum cuspidatum Ehrh. ex Hoffm. - Sokal District: near Prystan, forest cottage (Bradis, Kucheryava, 1956; KW); Volytsky Botanical Reserve, Pine forest, sphagnum-cranberry swamp, 50¹7'19.0'N 2358'30.6'E (Drach, Mamchur, 2018); near Kulychkiv, 2 forest quarter, mixed swampy forest, 50¹7'05.5'N 2406'14.7'E (Drach, Mamchur, 2018); near Sosnivka, Sosnivka forestry, swamp (Kuzyarin, 2008; LWS).

Distribution in Ukraine: Polissya, Carpathian Mountains, Forest steppe, Steppe.

$N H B$ : Б3 Mesotrophic mires. Б4.2 Spring fens. B1.1.4 Dystrophic waters with macrophyte vegetation. Д2.5.2 Bogs with layer of pine.

EUNIS: C1.4 Permanent dystrophic lakes, ponds and pools. D2.3 Transition mires and quaking bogs. G3.E Nemoral bog conifer woodland. G4.1 Mixed swamp woodland. G5.6 Early-stage natural and semi-natural woodlands and regrowth. X04 Raised bog complexes.

Sphagnum fallax (Klinggr.) Klinggr. (S. recurvum var. recurvum P. Beauv., S. recurvum var. mucronatum (Russ.) Warnst.) - Sokal District: $1 \mathrm{~km}$ northward from Sosnivka, wet meadow (Kuzyarin, 2003, 2006; LWS), Volytsky Botanical Reserve, Pine forest, sphagnum-cranberry swamp, 50¹7’29.0”N 2358'13.6”E ( Kuzyarin, 1991; LWS; Drach, Mamchur, 2018); near Kulychkiv, 2 forest quarter, mixed swampy forest, $50^{\circ} 17^{\prime} 07.5^{\prime \prime} \mathrm{N} 24^{\circ} 06^{\prime} 20.8^{\prime \prime} \mathrm{E}$ (Drach, Mamchur, 2018), Kamianka-Buzka District: northeast of Tadani, forest swamp of Eriophorum and Sphagnum (Kuzyarin, 1993; LWS).

Distribution in Ukraine: Polissya, Carpathian Foothills, Carpathian Mountains, Forest steppe, Steppe.

NHB: Б3 Mesotrophic mires. 54.1 Raised bogs. 54.2 Spring fens. B1.1.4 Dystrophic waters with macrophyte vegetation. Д1.5.3 Wet oligomesotrophic birch forests. Д1.7.2 Bogs with 
layer of birch. Д2.1.1 Lowland spruce forests. Д2.2.3 Wet Scots pine forests. Д2.5.1 Bogs with spruce layer. Д2.5.2 Bogs with layer of pine.

EUNIS: C1.4 Permanent dystrophic lakes, ponds and pools. D1.1 Raised bogs. D2.3 Transition mires and quaking bogs. G1.5 Broadleaved swamp woodland on acid peat. G3.1. Abies and Picea woodland. G3.E Nemoral bog conifer woodland. G4.1 Mixed swamp woodland. G5.6 Early-stage natural and semi-natural woodlands and regrowth. X04 Raised bog complexes.

Sphagnum fimbriatum Wils. - Sokal District: $1 \mathrm{~km}$ northward from Sosnivka, sedge-sphagnum swamp (Kuzyarin, 2003; LWS); Volytsky Botanical Reserve, Pine forest, sphagnum-cranberry swamp, 50¹7'19.0”N 2358'30.6”E (Kuzyarin, 1991; LWS; Drach, Mamchur, 2018); near Kulychkiv, 2-3 forest quarter, mixed swampy forest, 50¹7'00.7' N 24 06'38.1'E (Drach, Mamchur, 2018); Busk District: southward of Polonychi, right bank of the river Poltva, Pine forest (Kuzyarin, 2003; LWS); southwest of Bohdanivka, Pine forest, mesotrophic sphagnum swamp (Kuzyarin, 1996; LWS).

Distribution in Ukraine: Polissya, Carpathian Foothills, Carpathian Mountains, Forest steppe, Steppe.

NHB: Б3 Mesotrophic mires. Б4.1 Raised bogs. Б4.2 Spring fens. Д1.7.2 Bogs with layer of birch. Д2.2.3 Wet Scots pine forests. Д2.5.2 Bogs with a layer of pine. C3.5 Anthropogenic outcrops, spoil tips and tailings without vegetation.

EUNIS: C1.4 Permanent dystrophic lakes, ponds and pools. D1.1 Raised bogs. D2.3 Transition mires and quaking bogs. G1.5 Broadleaved swamp woodland on acid peat. G3.1 Abies and Picea woodland. G3.E Nemoral bog conifer woodland. G4.1 Mixed swamp woodland. G5.6 Early-stage natural and semi-natural woodlands and regrowth. X04 Raised bog complexes. J3 Extractive industrial sites.

Sphagnum flexuosum Dozy \& Molk. (S. recurvum var. amblyphyllum (Russ.) Warnst.). Sokal District: near Prystan, forest cottage, mesotrophic sedge-sphagnum swamp (Bradis, 1956) [23].

Distribution in Ukraine: Polissya, Carpathian Mountains, Forest steppe.

NHB: 53 Mesotrophic mires. Б4.2 Spring fens.

EUNIS: D2.2 Valley mires, poor fens and transition mires. D2.3 Transition mires and quaking bogs.

Sphagnum girgensohnii Russow (S. fimbriatum var. strictum Lindb.) - Sokal District: Volytsky Botanical Reserve, Pine forest, sphagnum-cranberry swamp, 50¹7'19.0'N 2358'30.6”'E (Drach, Mamchur, 2018); Chervonohrad mining region, coal dumps of mines « Nadiya» (Kuzyarin, 2013) [13, 14].

Distribution in Ukraine: Polissya, Carpathian Foothills, Carpathian Mountains, Forest steppe.

NHB: 52.1.2 Rich fens with calcium-tolerant sphagnum mosses. Б3 Mesotrophic mires. Д2.1.1 Lowland spruce forests. Д2.2.3 Wet Scots pine forests. C3.5 Anthropogenic outcrops, spoil tips and tailings without vegetation.

EUNIS: D2.3 Transition mires and quaking bogs. D4.1 Rich fens, including eutrophic tallherb fens and calcareous flushes and soaks. G3.1 Abies and Picea woodland. G3.E Nemoral bog conifer woodland. J3 Extractive industrial sites.

Sphagnum inundatum Russow (S. subsecundum var. inundatum (Russow) C. Jensen) Zhovkva District: near Zavady, the valley of the river Mlynivka, ditch near forest, 50 05'08.7'N 235'16.7'E (Mamchur, 2017).

Distribution in Ukraine: Carpathian Mountains, Polissya, Forest steppe. 
NHB: 63 Mesotrophic mires. B4.1.3 Riverine mesotrophic vegetation on muddy substrata. EUNIS: D2.3 Transition mires and quaking bogs.

Sphagnum magellanicum Brid. - Sokal District: Volytsky Botanical Reserve, Pine forest swamp (Kuzyarin, 2012; LWS); Kamianka-Buzka District: $3 \mathrm{~km}$ northeast of Tyshytsya, Pine forest swamp (Kuzyarin, 2010; LWS).

Distribution in Ukraine: Polesia, Carpathian Mountains Forest steppe, Steppe.

NHB: Б3 Mesotrophic mires. Б4.1 Raised bogs. Д1.5. Wet oligomesotrophic birch forests. Д1.7.2 Bogs with layer of birch. Д2.2.3 Wet Scots pine forests. Д2.5.1 Bogs with spruce layer. Д2.5.2 Bogs witha layer of pine.

EUNIS: D1.1 Raised bogs. D2.3 Transition mires and quaking bogs. G1.5 Broadleaved swamp woodland on acid peat. X04 Raised bog complexes. G3.E Nemoral bog conifer woodland /. G4.1 Mixed swamp woodland. G5.6 Early-stage natural and semi-natural woodlands and regrowth.

Sphagnum obtusum Warnst. (S. recurvum var. obtusum Warnst.) - Sokal District: Volytsky Botanical Reserve, Pine forest swamp (Bradis) [23].

$N H B$ : 54.2 Spring fens.

EUNIS: D2.3 Transition mires and quaking bogs.

Sphagnum palustre L. - Sokal District: Volytsky Botanical Reserve, Pine forest, sphagnum-cranberry eutrophic swamp, $50^{\circ} 17^{\prime} 19.0^{\prime \prime} \mathrm{N} 23^{\circ} 58^{\prime} 30.6^{\prime \prime} \mathrm{E}, 50^{\circ} 17^{\prime} 29.0^{\prime \prime} \mathrm{N} 23^{\circ} 58^{\prime} 13.6^{\prime \prime} \mathrm{E}$ (Bradis, Kucheryava, 1956; Kuzyarin, 1991; LWS; Drach, Mamchur, 2018) [23]; near Kulychkiv, 2 forest quarter, mixed swampy forest $50^{\circ} 17^{\prime} 00.7^{\prime \prime} \mathrm{N} 24^{\circ} 06^{\prime} 38.1^{\prime \prime} \mathrm{E}, 50^{\circ} 16^{\prime} 53.8^{\prime \prime} \mathrm{N} 24^{\circ} 06^{\prime} 48.8^{\prime \prime} \mathrm{E}$ (Drach, Mamchur, 2018); southward of Kariv, deforestation of Pine forest (Kuzyarin, 1991; LWS); near Dvirtsi, Pine forest (Kuzyarin, 2008; LWS); $1 \mathrm{~km}$ northward from Sosnivka, wet meadow (Kuzyarin, 2003, 2006; LWS); Zolochiv District: southwest of Pecheniya, bog (Kuzyarin, 2004; LWS).

Distribution in Ukraine: in all nature zones.

NHB: Б3 Mesotrophic mires. 54.2 Spring fens. Д1.5.3 Wet oligomesotrophic birch forests. Д1.7.1 Eutrophic swamps with layer of black alder or birch Д2.1.1 Lowland spruce forests. Д2.2.3 Wet Scots pine forests.

EUNIS: D2.3 Transition mires and quaking bogs. G4.1 Mixed swamp woodland. G1.5 Broadleaved swamp woodland on acid peat. G3.1 Abies and Picea woodland. G3.E Nemoral bog conifer woodland.

Sphagnum papillosum Lindb. - Sokal District: $1 \mathrm{~km}$ northward from Sosnivka, wet meadow (Kuzyarin, Virchenko, 2003; KW).

Distribution in Ukraine: Carpathian Mountains, Polissya, Forest steppe.

NHB: 54.1 Raised bogs. Б4.2 Spring fens. Б3 Mesotrophic mires.

EUNIS: D1.1 Raised bogs. D2.3 Transition mires and quaking bogs.

Sphagnum squarrosum Crome - Sokal District: near Kulychkiv, 2 forest quarter, mixed swampy forest, $50^{\circ} 17^{\prime} 07.5^{\prime \prime} \mathrm{N} 24^{\circ} 06^{\prime} 20.8^{\prime} \mathrm{E}$ (Drach, Mamchur, 2018); $1 \mathrm{~km}$ northward from Sosnivka, mesotrophic sphagnum swamp (Kuzyarin, 2003; LWS); Kamianka-Buzka District: northeast of Tadani, Pine forest, mesotrophic sphagnum swamp (Kuzyarin, 1993; LWS).

Distribution in Ukraine: Polissya, Carpathian Mountains Forest steppe, Steppe.

NНВ: Д2.1.1 Lowland spruce forests. Б4.2 Spring fens. Б3 Mesotrophic mires. Д1.7.1 Eutrophic swamps with layer of black alder or birch.

EUNIS: D2.3 Transition mires and quaking bogs. G3.1 Abies and Picea woodland. G4.1 Mixed swamp woodland. 


\section{REFERENCES}

1. Boiko M. F. Rare bryophytes from plane and mountain landscapes of Ukraine// Chornomors'k. bot. z. 2010. № 6 (3). P. 294-315. (In Ukrainian)

2. Boiko M. F. The Second checklist of Bryobionta of Ukraine // Chornomors'k. bot. z. 2014. Vol. 10 (4). P. 426-487. http://doi:10.14255/2308-9628/14.104/2.

3. Bradis Ye. M. Bachuryna H. F. Wetlands of the USSR. K.: Nauk. dumka, 1969. 244 p. (In Ukrainian)

4. Davies C. E., Moss D., Hill M. O. EUNIS Habitat Classification, Revised // Report to European Environment Agency-European Topic Centre on Nature Protection and Biodiversity. 2004. 310 p.

5. Ellenberg H., Leuschner C. Zeigerwerte der Pflanzen Mitteleuropas. In: Vegetation Mitteleuropas mit den Alpen: in ökologischer, dynamischer und historischer Sicht. Utb. 2010. $1334 \mathrm{~s}$.

6. Garrett A. K. Systematics of the Sphagnum recurvum Complex: Morphological Variation, Hybridization and the Delineation of Intermediate Taxa. Diss. Duke University, 2015. 62 p.

7. Glime J.M. Life Cycles and Morphology. Bryophyta - Sphagnopsida in: Bryophyte ecology // Ebook sponsored by Michigan Technological University and the International Association of Bryologists. 2007 http://www.bryoecol.mtu.edu.

8. Herenchuk K. I. Nature of the Lviv Region. Lviv University, 1972. 152 p. (In Ukrainian)

9. Herenchuk K. I., Koynova M. M., Tsys P. M. Natural and geographical division of Lviv and Podolian economic districts. Lviv University, 1964. 221 p. (In Ukrainian)

10. Hill M. O., Preston C. D., Bosanquet S. D. S., Roy D. B. BRYOATT: attributes of British and Irish mosses, liverworts and hornworts // Centre for Ecology and Hydrology. NERC Centre for Ecology and Hydrology and Countryside Council for Wales. 2007. 88 p. http://nora.nerc. ac.uk/1131/1/BRYOATT.pdf.

11. Hofmann H., Müller N., Schnyder N. Merkblätter Artenschutz Moose // BAFU, NISM, FUB 2006. 24 p. https:/www.swissbryophytes.ch/documents/naturschutz/Artenschutz Moose_D.pdf.

12. Jones $\bar{C}$. G, John H. L, Moshe S. Organisms as ecosystem engineers // NY, USA: Ecosystemmanagement, Springer, 1994. Vol. 69 (3). P. 130-147.

13. Karpinets L. I., Lobachevska O. V., Sokhanchak R. R. Ecological structure of epigeic synusiae of mosses on rock dumps of Chervonograd industrial mining region // Ukr. Bot. J. 2017. Vol. 74(2). P. 154-162. (In Ukrainian)

14. Kuzyarin O. T. Bryoflora of coal dumps of Lviv-Volynian mining region // Studia Biologica. 2013. Vol. 7 (1). P. 105-114. (In Ukrainian)

15. Lviv region: natural conditions and resources: monograph / ed. Dr. Geogr. of sciences, prof. M.M. Nazaruk. Lviv: The Old Lev Publishing House, 2018. 592 p. (In Ukrainian)

16. Mamchur Z., Drach Yu., Chuba M. The rare species of mosses of high mountains part of the Ukrainian Carpathians: Marmaros and Chornohora ranges // Visnyk of the Lviv University. Series Biology. 2019. Issue 80. P. 118-128. DOI: http://dx.doi.org/10.30970/vlubs.2019.80.13 (In Ukrainian)

17. National habitat catalogue of Ukraine // ed. A.A. Kuzemko, Ya.P. Diduch, V.A. Onyshchenko, Ya. Shaffer. Kyiv. FOP Klymenko Yu.Ya, 2018. 442 p. (In Ukrainian)

18. Pankiv Z. P. Land resources. Lviv, 2008, 272 p. (In Ukrainian)

19. Rozporządzenie Ministra Środowiska z dnia 9 października 2014 r. w sprawie ochrony gatunkowej roślin. 2014. $37 \mathrm{~s}$.

20. Rydin H., Jeglum J. K. The biology of peatlands. 2nd edn. Oxford University Press, Oxford, UK, 2005. $382 \mathrm{p}$. 
21. Sokal District Environmental Protection Program for 2016-2020 http://rajrada.sokal.lviv. $\mathrm{ua} / \mathrm{p}=79033$

22. Weston D. J., Turetsky M. R., Johnson M. G. et al. The sphagnome project: enabling ecological and evolutionary insights through a genus-level sequencing project // New Phytologist. 2018. Vol. 217 (1). P. 16-25.

23. Zerov D. K. Flora of hepatic and sphagnum mosses of Ukraine. Kyiv: Nauk. dumka, 1964. 355 p. (In Ukrainian)

Стаття надійшла до редакиії 14.02.20

доопрачьвована 20.07.20

прийнята до друку 22.07.20

\title{
СФАГНОВІ МОХИ МАЛОГО ПОЛІССЯ (ЛЬВІВСЬКА ОБЛАСТЬ)
}

\author{
3. Мамчур, Ю. Драч, С. Притула
}

Львівський національний університет імені Івана Франка вул. Грушевського, 4, Львів 79005, Украӥна

e-mail:dzvinkamamchur@gmail.com

У статті узагальнено сучасні відомості про стан і поширення сфагнових мохів на території Малого Полісся у Львівській області на основі власних польових досліджень, літературних і гербарних (Національного Гербарію НАН України (KW), Гербарію Державного природознавчого музею НАН України (LWS) даних. Укладено анотований список видів роду Sphagnum, що включає 15 видів, із зазначенням місць i дати збору, імен колекторів, поширення в Україні та біотопів, у яких трапляється вид, згідно з Національним каталогом біотопів України та EUNIS. Встановлено, що Sphagnum fallax (Klinggr.) Klinggr., S. fimbriatum Wils. i S. palustre L. є найпоширенішими видами роду сфагнум на території дослідження. Два види - S. angustifolium (C. Jensen ex Russow) C. Jensen та S. inundatum Russow - уперше наведені для Львівської області.

Виявлено шість регіонально рідкісних видів: S. capillifolium (Ehrh.) Hedw., $S$. cuspidatum Ehrh. ex Hoffm., S. fallax, S. fimbriatum, S. obtusum Warnst. i S. papillosum Lindb. Зазначено можливе зникнення на території Волицького державного ботанічного заказника видів Sphagnum centrale C. Jensen, S. contortum Schultz, S. obtusum i S. flexuosum Dozy \& Molk. унаслідок проведення тут гідромеліоративних робіт.

Проаналізовано екологічні групи видів сфагнів на території дослідження, встановлено переважання субгеліофітів (7 видів, 46,7 \%), гігрофітів (13 видів, 86,7 \%), холодотолерантних видів (13, або 87,7 \%) і ацидофілів (8 видів, 53,3 \%).

Показано актуальність вивчення сфагнів, оскільки вони поширені значно рідше, ніж інші види з відділів мохоподібних, бо приурочені до вузького кола біотопів. А за кардинальних змін гідрологічного режиму середовища, що відбувались упродовж другої половини XX ст., зважаючи на значні площі осушених земель, процеси зневоднення біотопів стали незворотними, і деякі види сфагнів могли зникнути 3 території Малого Полісся.

Зважаючи на чутливість мохоподібних, зокрема, видів роду сфагнум, до порушення гідрологічного режиму водно-болотних угідь, заболочений мішаний ліс в околицях села Куличків $є$ перспективною територією для створення нового природоохоронного об'єкта або розширення меж Волицького ботанічного заказника 3 метою збереження тут болотних біотопів.

Ключові слова: сфагнові мохи, Мале Полісся, Волицький заказник, біотопи 